\title{
HOUDING, KENNIS EN GELUK VAN VERPLEEGPERSONEEL WAT IN TEHUISE VAN BEJAARDES WERKSAAM IS
}

\author{
PP du Rand en MV Vermaak
}

\begin{abstract}
According to the literature, the quality of nursing care in homes for the aged is largely determined by the attitude and krowledge of the nursing staff towards and about old people.
\end{abstract}

A study was conducted in ten units for the frail aged to determine these two factors, as well as the job satisfaction of the staff. Although almost $100 \%$ of the nursing staff expressed satisfaction with their jobs, many of them revealed prejudices towards and a lack of knowledge about the nursing care needs of the aged.

\section{OPSOMMING}

Volgens die literatutur word die gehalte van verpleegsorg in tehuise vir bejaardes tof'n groot mate bepaal deur die houding en kennis van die verpleespersoneet teenoor en van bejaardes.

'n Studie is in tien eenhede vir verswakte bejaardes onderneem om hierdie twee faktore, sowel as die werkstevredenheid van die verpleegpersoneel te bepaal. Alhoewel byna $100 \%$ van die verpleegpersoneel verktaar het dat hulte tevrede en gelukkig is in hulle werk, het baie van hulle vooroordele teenoor en'n gebrek aan kennis van die verpleegsorgbehoeftes van bejaardes geopenbaar.

\section{INLEIDING}

Hierdie is die tweede in 'n reeks van twee artikeis oor 'n projek om die kwaliteit van verpleegsorg in tehuise van bejaardes te bepaal. In hierdie artikel gaan dit oor die belangrikste determinante $\mathrm{v}$ an $\mathrm{kwaliteit}$ in die versorging van bejaardes, naamlik die houding en kennis van die verpleegpersoneel, en faktore wat daarmee verband hou.

\section{LITERATUURSTUDIE}

Houding van verpleegpersoneel teenoor bejaardes

'n Faktor waarvan die verpleegpersoneel wat met bejaardes werk, onbewus mag wees, is hul houding teenoor bejaardheid. Dit is bekend dat bejaardes nie van waarde geag word nie, omdat dit veral vir die jeug belangrik is dat ' $n$ persoon fisieke en psigologiese bydraes tot die samelewing moet mak (Murray \& Zentner 1985:545; Slabber 1985:1.4; en Seers 1986:51). Negatiewe houdings teenoor bejaardes word ook deur verpleegpersoneel in die Westerse samelewing gehandhaaf (Scottet al. 1991:21). Daar is bevind dat verpleegpersoneel onwillig is om met bejaardes te werk (Delora \& Moses 1969; Campbell 1971; Gunter 1971; Gillis 1973; en Kayser \& Minnigerode 1975). Armstrong-Esther et al. (1989:40) som dit soos volg op: "Thus the elderly are still perceived generally as an unattractive group with whom to work". Hierdie negatiewe houding is verantwoordelik vir die onbevredigende behandeling van bejaarde pasiënte (Ingham \& Fielding 1985:1771. Chandler et al. 1986:155; en Nodhturft et al. 1986:28). Boorer (1970, aangehaal in Wells 1980:30) maak die volgende stelling:

"There seems to be general agreement that a nurse's attitude influences the standard of care received by patients".

Volgens Heller et al. (1984:23) word sorg nie op 'n aanvaarbare vlak aan geinstitusionaliseerde bejaardes gelewer nie omrede verpleegpersoneel se siening van verpleegsorg slegs bewaarsorg (custodial care) eerder as rehabilitasie is. Hulle beskou bejaardes in tehuise as "too far gone and senile to respond to any restorative activities". Kahana en Kiyak (1981) in Heller et al. (1984:25) se resultate van 'n studie van tehuise dui daarop dat hoe meer positief die houding van personeel is hoe groter is die kans dat onafhanklikhid by die bejaardes aangemoedig sal word. In genoemde studie was daar 'n betekenisvolle verhouding tussen houding en persepsie van sorg. Daar is bevind dat negatiewe houdings teenoor bejaardes meer dikwels verband gehou het met persepsies van bewaarsorg terwyl positiewe houdings met rehabilitatiewe oriëntasies gepaard gaan
(Heller et al. 1984:25). Personeel se houding beinvloed dus hul oriëntasie tot behandeling en dit kan 'n invloed op die kwaliteit van sorg uitoefen (Yurick et al. 1980:97).

\section{KENNIS VAN VERPLEEGPERSONEEL}

Volgens Slevin (1991:1204) blyk dit dat voldoende kennis kan help om personeel se houding teenoor bejaardes positief te beinvloed. Daar word ook algemeen aanvaar dat hoë kwaliteit verpleegsorg sonder dat die personeel oor die nodige kennis beskik nie moontlik is nie. Tog blyk dit dat die noodsaaklikheid van gespesialiseerde kennis van geriatriese verpleging soms nie belangrik genoeg geag word nie. Die volgende aanhalings is voorbeelde hiervan:

"Geriatric nursing is the basis of all good nursing - it is common sense" (Castledine 1982:19).

"Nurses don't believe that there's any special knowledge needed to care for the older person" (Brower et al. 1982:12).

Vandag met die toenemende getal bejaardes wat hulself nie meer selfstandig kan versorg nie en wat as verswaktes geklassifiseer is, is verpleegpersoneel wat oor die nodige kennis beskik met betrekking tot die hantering van bejaardes 'n vereiste (Nodhturft et al. 1986:25; Smith 1990:8; Slevin 1991:1204).

\section{OPERASIONELE DEFINISIES}

Houding

'n Persoon se gesindheid of opinie teenoor ' $n$ saak, persuon of groep. Dit dui op die persoon se voorkeur of afkeur teenoor die bepaalde saak persoon of groep.

\section{Kennis}

Professionele inligting en insig waaroor die persoon beskik ten opsigte van aspekte wat met verpleegsorg in tehuise van bejaurdes verband hou.

\section{Geluk}

Die gevoel van tevredenheid waaroor die persoon in die werksituasie beskik. 


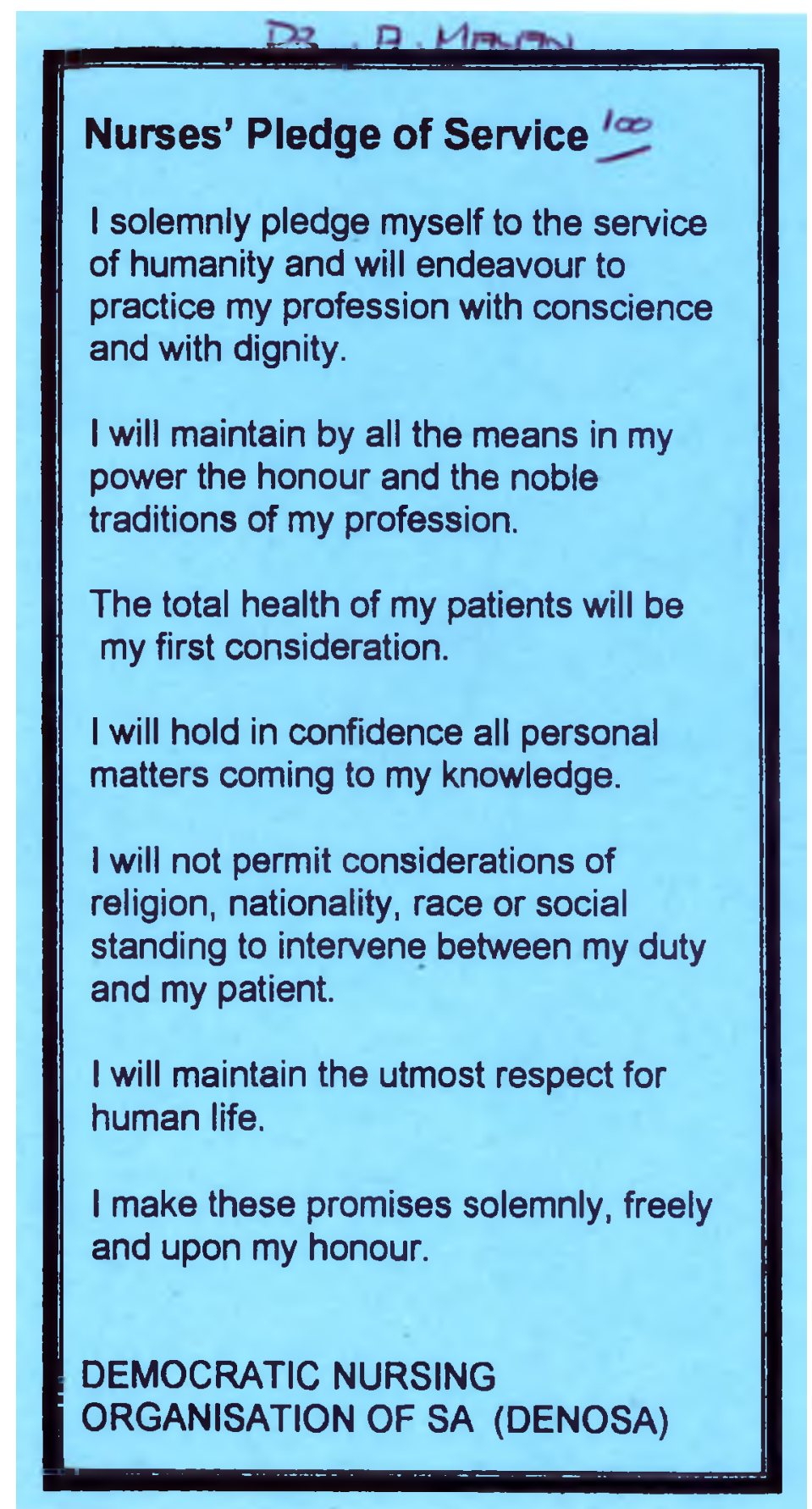




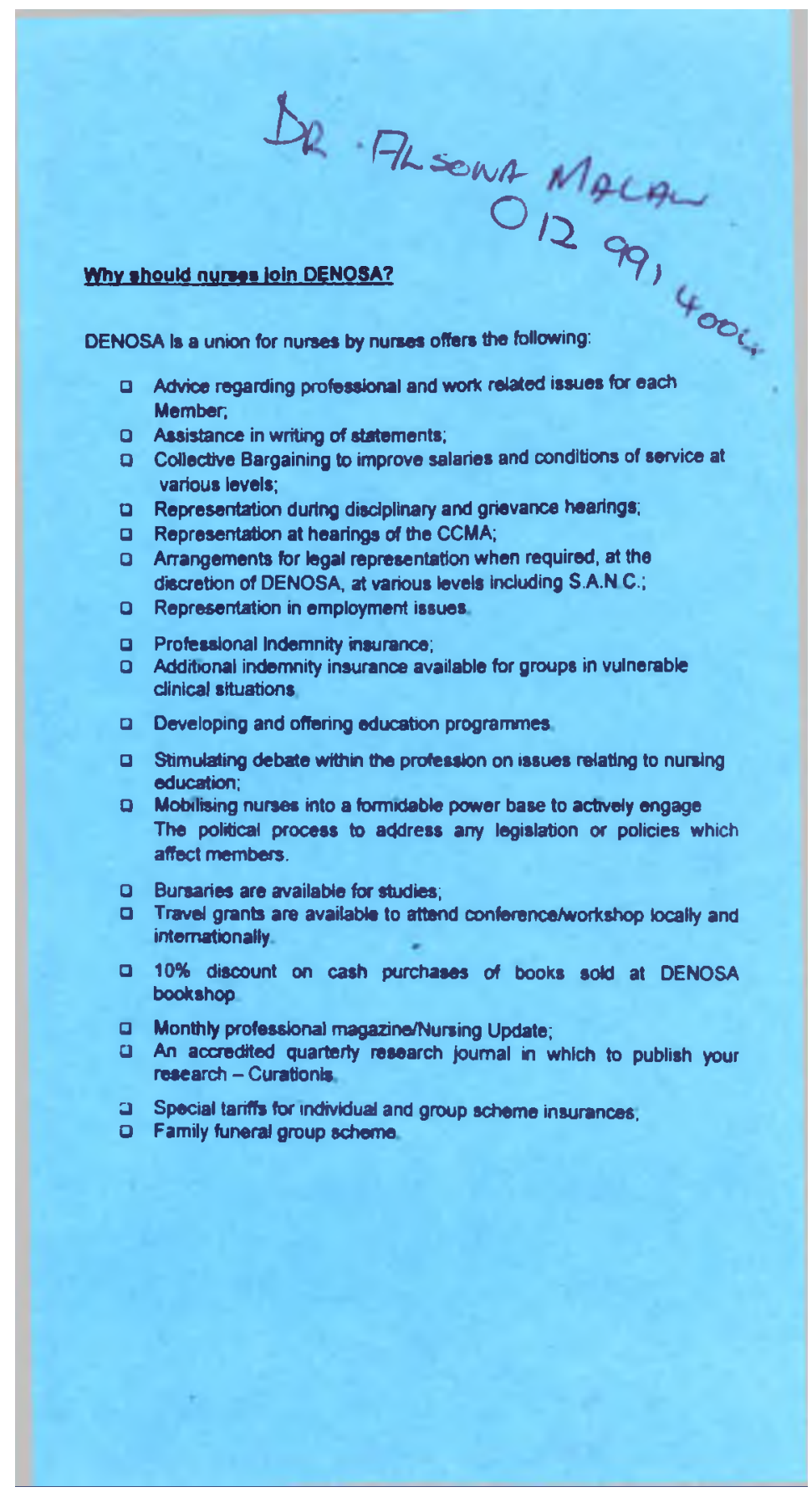


Om:

- die houding en kennis van verpleegpersoneel wat in tehuise van bejaardes werksaam is te bepaal

- te bepaal tot watter mate hulle werkstevredenheid ervaar

- ander faktore wat houding en kennis kan beinvloed, naamlik demografie, personeelomset, uitbranding en die voorsiening van indiensopleiding vas te stel

\section{NAVORSINGSONTWERP}

Die opname metode is gevolg en die navorsing is beskrywend van aard.

\section{DATA-INSAMELINGSINSTRUMENTE}

'n Vraelys is deur die navorser opgestel om te bepaal wat die huidige situasie in Vrystaatse tehuise is ten opsigte van die aspekte soos hieronder uiteengesit. Dit bestaan uit twee afdelings. Afdeling $A$ is deur alle kategoriee verpleegpersoneel en Afdeling B slegs deur geregistreerde verpleegkundiges voltooi.

Uiteensetting van die vraelys

\section{Afdeling A}

Vrae 1 en 2 Demografiese data

Vrag $3 \quad$ Personeelomset

Vrae 4.6 Kwalifikasiebepaling

Vraag $7 \quad$ Aard van indiensneming

Vraag $8 \quad$ Tevredenheid van personeel met salaris, byvoordele en voorraad en tocrusting in tehuise

$\begin{array}{ll}\text { Vraag } 9 & \text { Rede vir werk in tehuis } \\ \text { Vraag 10 } & \text { Bepaling van rolstatus } \\ \text { Vraag 11 } & \begin{array}{l}\text { Bepaling van werks. } \\ \text { tevredenheid }\end{array}\end{array}$

Vraag 12 Vasstelling van tekens van uitbranding

Vraag 13 Vasstelling van wie die kliniese besluitneming doen

Vraag $14 \quad$ Inligting met betrekking tot indiensopleiding

Vraag $15 \quad$ Kennis oor voetversorging

Vraag 16 Bepaling van houding en kennis

$\begin{array}{ll}\text { Vraag } 17 \text { (slegs } & \begin{array}{l}\text { Toets kennis van } \\ \text { farmakologie }\end{array} \\ \text { veregistreerde } & \end{array}$

Vraag 16 bestaan uit 17 stellings in die vorm van 'n Likert-skaal om die houding en kennis van die personeel te bepaal.

Houdingsbepaling deur middel van 'n vraelys is kompleks en problematies. Die verskillende instrumente wat in die literatuur beskikbaar is, is dus geraadpleeg en bestudeer (Tuckman \& Lorge 1953:249-260; Kogan 1961:44-54; Palmore 1977 en 1981; Snape 1985:569-572). Geen Suid-Afrikaanse skaal kon in die literatuur gevind word nie.

Die rede hoekom die navorser nie een van bogenoemde skale gekies het nie, is omdat dit Amerikaanse skale is en lank gelede opgestel is, byvoorbeeld Tuckman en Lorge (1953) sowel as Kogan (1961). Sommige het ' $n j a / n e e$ respons en ander is in die vorm van 'n Likert-skaal. Die geldigheid en betroubaarheid van sommige van die skale word ook in die literatuur bevraagteken (Campbell 1971:148; Wells 1980:33; Chandler, Rachal \& Kazelskis 1986:553).

Die vasstelling van die personeel se houding teenoor aspekte van bejaardheid is ' $n$ belangrike faktor wat in die huidige studie bepaal moes word. $\mathrm{Na}$ ' $\mathrm{n}$ deeglike literatuurstudie is ' $n$ aantal bewerings gemaak ten opsigte van bejaardheid, verswakte bejaardes en sekere aspekte van verpleegsorg. Dit is in die vorm van 'n Likert-skaal aangebied. Die vyf kategorieë is: Stem beslis saam. Stem saam. Staan neutraal, Stem nie saam nie, Stem beslis nie saam nie. Daar is van die respondente verwag om op die skaal aan te dui tot watter mate hulle met elke stelling saamstem (Nel 1978:60). Daarna is daar in totaal vir elke kategorie 'n puntetoekenning gemaak op grond van die response'.

\section{Afdeling B - Vraag 17}

Hierdie vraag bepaal die geregistreerde verpleegkundiges se insig in farmakologie. Die vraag bestaan uit 13 stellings in die vorm van 'n Likert-skaal. 'n Puntetoekenning word egter nie gemaak nie. Die vraag is ingesluit om die verpleegkundiges se kennis van geneesmiddel interaksies en newe-effekte te bepaal aangesien bejardes baie geneesmiddels gebruik.

Geldigheid en betroubaarheid van die vraelyste

Inhoudsgeldigheid en sigsgeldigheid is in elke domein van die ontwikkelingstadium na 'n deeglike literatuurstudie bepaal. Daar is

1. Die hoogate waarde, vyl, word toegeten as in rexpondent "Beslis saamstem" met 'n stelling wat in gunstige arekking ha. Die waande word egter ongeteer vir ongunstige dellingt, dit wil set 'n respondent wat "Gled nie caamstem" met in ongunstige stelling nie verdien vyf punte darvoor. gepoog om voldoende vrae in te sluit om die doelstelling te bereik.

Sewe domeinkundiges (almal senior verpleegkundiges met praktyk en navorsings-ervaring) is gevra om die vraelys te beoordeel. Die opdrag aan die kundiges was om aan die hand van die breë navorsingsdoelstelling te bepaal:

- of die vrae verteenwoordigend is van die domein soos in die doelstelling gespesifiseer (Wilson 1989:357),

- of die doelstelling bevredigend in die vrae ingebou is, en

- hulle het ook op die voorkoms van die vraelys gelet.

Nadat die vraelyste deur die domeinkundiges beoordeel is, is die nodige regstellings aangebring en is die vraelyste in 'n loodsstudie uitgetoets.

Betroubaarheid is met die toets-hertoets-metode bepaal. Die instrument is in 'n loodsstudie aangewend aan ' $n$ verteenwoordigende steekproef $v$ an die teikenpopulasie. $\mathrm{Na}$ twee weke is die respondente gevra om weer die vraelys te voltooi. Volgens Wilson (1985:306) is daar nie ' $n$ vasgestelde standaard vir die interval van tyd tussen twee toetsings nie, maar dit moet lank genoeg wees om te verseker dat respondente nie in in staat is om hul response op die exste toediening te herroep nie. Die betroubaarheidskoëffisiënt is nie statisties bepaal nie. 'n Eksteme navorser het egter die vraelyste beoordeel nadat die toets-hertoets metode uitgevoer is. Die relatiewe konstantheid is op grond daarvan aanvaar.

\section{Loodsstudie}

'n Loodsstudie is vir die volgende redes uitgevoer:

om die:

- instrumente uit te toets

- betroubaarheid van instrumente te bepaal. en

- navorser ondervinding te gee met die respondente, metodologie en instrumente (Bums \& Grove 1987:57).

Daar is waargeneem dat dit vir die verpleegassistente 'n vreemde ervaring was om 'n vraelys te voltooi en dat hulle baie leiding en verduideliking benodig. Die navorser was die hele tyd tydens die voltooiing van die vraclys teenwoordig sodat hulle vry kon voel om vrae te vra.

Wat betref die vraelyste is geen teenstrydighede ten opsigte van betroubaarheidsbepaling gevind nie. 


\section{STEEKPROEF}

'n Gestratifiseerde ewekansige steekproef van al die blanke tehuise in die Oranje-Vrystaat is getrek. Die aspek wat vir stratifikasie gebruik is, is die grootte van die tehuis. 'n Stratifikasie van groot (tehuis met 40 of meer verswakte bejaardes) en 'n klein (tehuis vanaf 10-39 verswakte bejaardes) is gedoen. Al die ingeskrewe/geregistreerde personeel van die tehuise is gevra om die vraelyste te voltooi (die steekproef is volledig in die vorige artikel beskryf).

\section{VERLOOP VAN DIE NAVORSING}

\section{Verkryging van toestemming}

Met die beplanning van die navorsing is die samewerking van die Departement van Gesondheidsdienste en Welsyn verkry.

Nadat die steekproef getrek is, is daar vanaf die oorhoofse welsynorganisasies toestemming verkry om die navorsing in hulle tehuise te doen. Daarna is toestemming van elke beheerraad verkry. Daar was geen probleme met die verkryging van toestemming nie. Daarna is die verpleegkundiges in bevel van elke tehuis telefonies geskakel en 'n afspraak vir die besoek is gereël.

\section{Met aankoms by die tehuise}

Daar is begin deur ' $n$ onderhoud met die verpleegkundige in bevel te voer. Die doel van die studie is verduidelik en ook die werkswyse wat die navorser volg, naamlik dat:

- alle personeel wat by die SARV geregisteer/ingeskryf is gevra sal word om vraelyste onder toesig van die navorser in hulle teetyd te voltooi.

\section{Voltooiing van vraelyste}

Die vraelyste is onder toesig van die navorser voltooi. Aangesien daar vrae is wat insig en houding toets het die navorser se teenwoordigheid verhoed dat menings onder die respondente uitgeruil word. Baie aandag is aan die verpleegassistente verleen om die instruksies te verduidelik. Van die verpleegassistente het tot 30 minute geneem om die vraelys te voltooi. Tydens voltooiing van die vraelyste het die navorser voortdurend verduidelik en hulp aangebied. Daar is egter gewaak om nie die invul van die vraelys te beïnloed nie. Geregistreerde personeel het ook sover as moontlik die vraelyste onder toesig voltooi. Hulle het dit oor die algemeen maklik voltooi in omtrent 10 minute. Die navorser het gewoonlik tot na 19:00 gebly sodat die nagpersoneel ook die vraelys onder toesig kon voltooi.

\section{Afsluiting van besoek}

Nadat al die instrumente voltooi is, het die navorser die personeel vir hulle samewerking bedank en gegroet. ' $n$ Bedankingsbrief is ook aan die beheerraad sowel as die verpleegpersoneel gestuur. Die navorser is deur al die tehuise goed ontvang.

\section{DATA-ANALISE}

Die SPSS ${ }^{2}$ rekenaar program is gebruik om 'n frekwensie-ontleding en persentasies te bepaal.

\section{Interpretasie van data}

Daar was 83 verpleegassistente, agt ingeskrewe verpleegkundiges en 47 verpleegkundiges op die diensstate van die 10 tehuise. Een en tagtig $(97,6 \%)$ van die 83 , al agt ingeskrewes $(100 \%)$ en $45(95,7 \%)$ van die 47 verpleegkundiges het die vraelys voltooi.

\section{Ouderdomsamestelling van respondente}

Nege-en-tagtig $(66,4 \%)$ van die respondente was ouer as 40 jaar. Veertig $(29,9 \%)$ was tussen 50 en 60 jaar en nege $(6,7 \%)$ tussen 61-70 jaar. Die gemiddelde ouderdom was 40 jaar en hierdie bevinding strook met dié van Amerikaanse navorsers wie se studie 'n gemiddelde ouderdom van 39.03 jaar getoon het (Glasspoole \& Aman 1990:11).

Volgens Mezey en Lynaugh (1989:772) is verpleegpersoneel in tehuise gewoonlik ouer. Ongelukkig meld die skrywers nie wat hulle as ouer beskou nie. Die navorser is van mening dat "ouer" gewoonlik bokant 40 jaar beteken.

\section{Rassesamestelling van die respondente}

Hierdie gegewens is versamel om die aard en samestelling van die respondente wat by die studie betrokke was vas te stel. Honderd $(74,6 \%)$ was blank. Die swart personeel was in die minderheid $34(25,4 \%)$ en was almal verpleegassistente.

Volgens Burge (1978) in Ingham en Fielding (1985:174) kan ras 'n betekenisvolle invloed op houding hê. Wright (1988:815) het gevind dat daar soms vyandigheid tussen 'n swart personeellid en ' $n$ wit bejaarde is. Die navorser is van mening dat aangesien die persentasie van swart personeel in wit tehuise tans so klein is dit moontlik nie betekenisvol is nie.

Die navorser voorsien egter dat die persentasie swartes wat in die toekoms in die tehuise gaan werk groter sal word. Die verpleegkundige in bevel behoort haarself vroegtydig voor te berei om kultuurverskille te akkommodeer.

In die huidige studie was dit nie cen van die doelstellings om te bepaal of daar wrywing tussen swart personeel en wit bejaardes voorkom nie. Tydens die waarneming het dit egter nie vir die navorser voorgekom of daar konflik heers nie.

\section{Jare wat personeel in dieselfde tehuis} werksaam is

Hierdie vraag is ingesluit om 'n aanduiding van die personeelomset te verkry.
Drie-en-sewentig personeellede $(54,5 \%)$ het langer as vyf jaar in die betrokke tehuis gewerk, $28(20,9 \%)$ het meer as 10 jaar daar gewerk en slegs $10(7,5 \%)$ van die respondente was minder as cen jaar in die tehuis werksaam. Die personeelomset in Vrystaat tehuise is dus laer as dit wat in Amerikaanșe navorsing aangedui word. Volgens Philips (1987:50), Chartock (1988:505) en Brooke (1989:68) is dit gemiddeld $60 \%$. Waxman et al. (1984:503) het bevind dat die personeel omset tot met $500 \%$ per jaar kan styg.

Akademiese kwalifikasies van respondente

Twee-en-tagtig $(61,2 \%)$ van al drie kategoricë het nie oor 'n matrieksertifikaat beskik nie en 24 (17,9\%) beskik slegs oor 'n St. 6 sertifikaat. $V$ an die verpleegkundiges het slegs ses (4.5\%) 'n graad in verpleegkunde en nege-en-dertig beskik oor 'n Diploma in Verpleegkunde. Ongelukkig kon die navorsers as gevolg van die wyse waarop die vraag gestel is nie bepaal of al die verpleegkundiges oor St. 10 beskik nie. . In die vorige artikel is gemeld dat 'n bewaarsorg benadering in tehuise van bejaardes gevolg word. Dit kan moontlik toegeskryf word aan die feit dat byna twee-derdes van die personeel oor minder as 'n matrieksertifikaat beskik. 'n Rehabilitatiewe benadering noodsaak innoverende denke en daarvoor is persone met 'n hoër opleieingsvlak nodig.

\section{Professiunele registrasie van verpleegkundiges}

Figuur 1 dui aan dat $41(91.1 \%)$ van die respondente in algemene verpleegkunde gercgistreer was. Gegewens wat nie in figuur 1 weerspieël word nie, is dat drie $(6,6 \%)$ net in psigiatriese verpleging geregistreer was en een $(2.2 \%)$ net oor 'n verloskundige kwalifikasie beskik het. Die ideaal volgens die navorser se mening is dat die minimum vereistes Algemene, Psigiatriese en Gemeenskapsverpleegkunde behoort te wees. Op navraag is sy meegedeel dat die persone wat slegs oor psigiatrie en verloskunde beskik het aangestel is omdat beter gekwalifiseerders onverkrygbaar was. Dit het egter geblyk dat die persoon met net verloskunde goed in die tehuis funksioneer en een van die persone wat net oor psigiatrie beskik is die bestuurder van 'n tehuis.

Dit blyk ook uit die figuur dat die respondente nie oor al die basiese kwalifikasies beskik het nie. Wat opvallend is en met die literatuur ooreenstem, is dat wcinig naamlik agt $(17,8 \%)$ verpleegkundiges in psigiatriese verpleging geregistreer was (Trichard et al. 1982:624) Hierdie skrywer sowel as Amerikaanse navorsers beklemtoon dat kennis van psigiatriese verpleegkunde noodsaaklik is om gespesialiseerde sorg aan bejaardes te lewer (Hirst 1986:24; en Smith 1990:8).

Dertig $(66,7 \%)$ het 'n professionele registrasic in verloskunde gehad en slegs vyf $(11,1 \%)$ was in gemeenskapsverpleegkunde geregistreer. Die ouderdomsverspreiding van die 


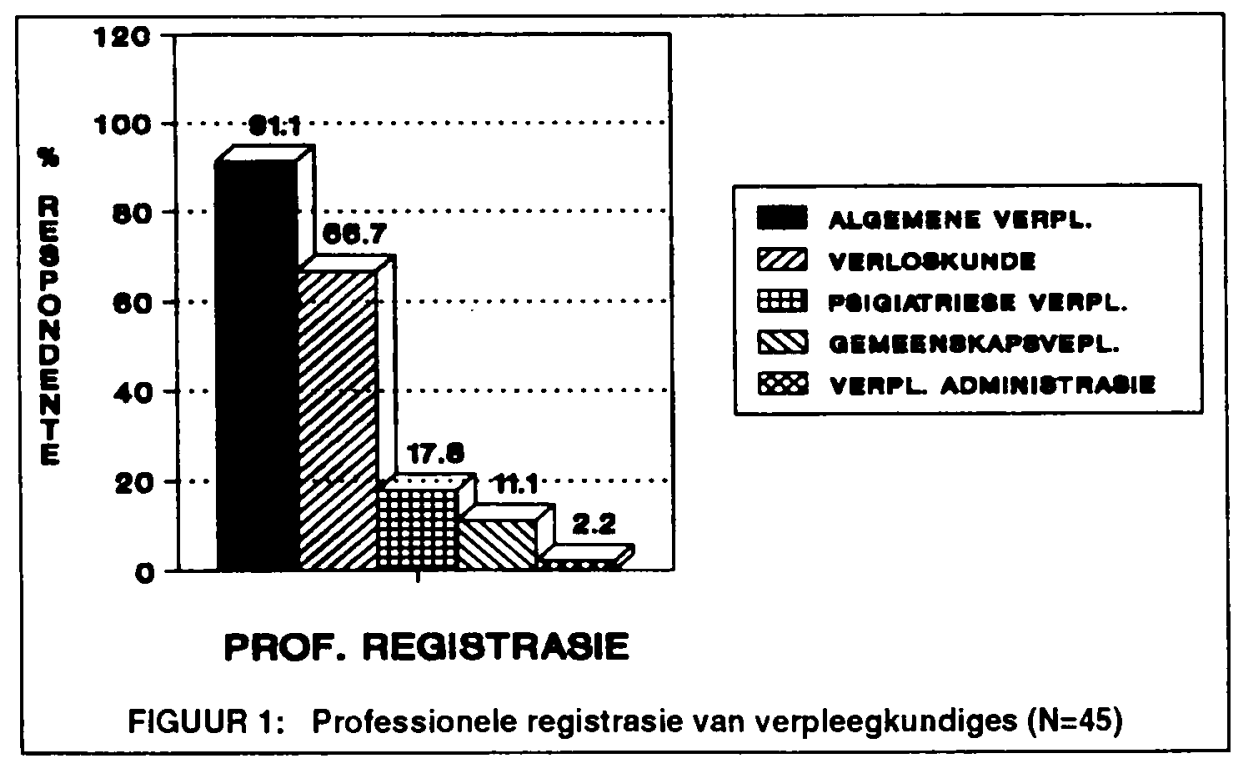

TABEL 1: Redes wat respondente gelukkig in hul werk maak $(N=134)$

\begin{tabular}{|lrr|}
\hline REDES & Frekwensie & $\%$ \\
Om bejaardes te kan help & 64 & 47,8 \\
Bejaardes se waardering vir hul versorging & 19 & 14,1 \\
Rustigheid van 'n tehuis & 2 & 1,5 \\
Goeie interpersoonlike verhoudings met & & \\
medepersoneel & 26 & 19,4 \\
Geen rede verskaf nie & 23 & 17,2 \\
\hline
\end{tabular}
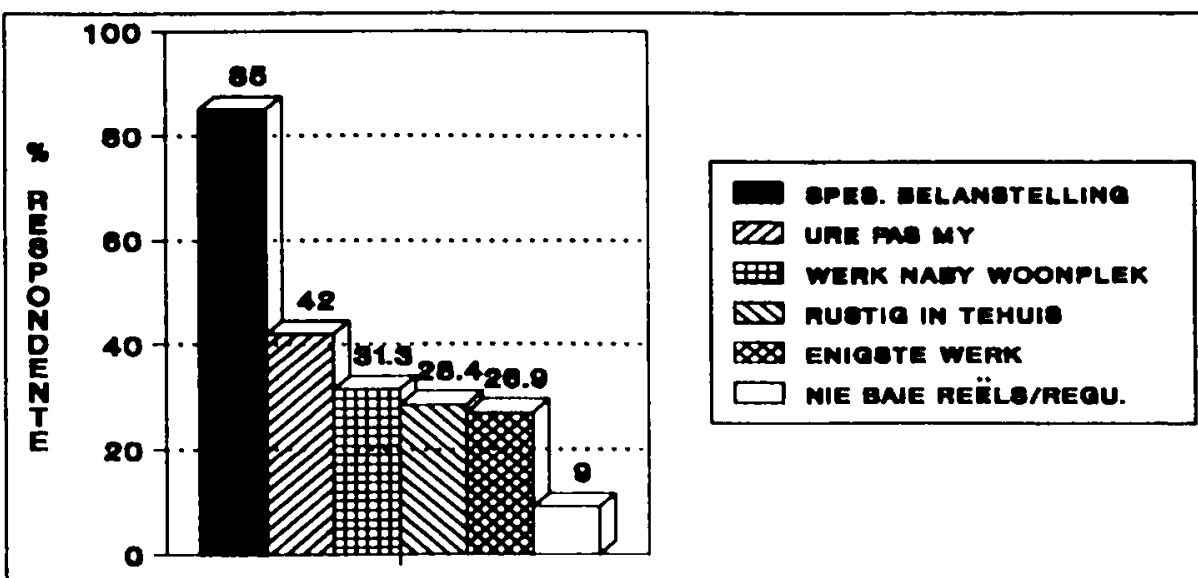

REDE8

FIGUUR 2: Redes hoekom respondente in ' $n$ tehuis vir bejaardes werk ( $N=134)$

\begin{tabular}{|l|r|r|r|r|}
\hline \multicolumn{5}{|c|}{$\begin{array}{c}\text { TABEL 2: Tevredenheid of ontevredenheid van } \\
\text { personeel met diensvoorwaardes }\end{array}$} \\
\hline $\begin{array}{l}\text { PERSONEEL TEVREDENHEID/ } \\
\text { ONTEVREDENHEID }\end{array}$ MET DIENSVOORWAARDES & \multicolumn{2}{|c|}{$\begin{array}{c}\text { Tevrede } \\
\text { Ja }\end{array}$} & \multicolumn{2}{|c|}{$\begin{array}{c}\text { Ontevrede } \\
\text { Nee }\end{array}$} \\
\cline { 2 - 6 } & $F$ & $\%$ & $F$ & $\%$ \\
\hline Salaris $(\mathrm{N}=133)$ & 96 & 72,2 & 37 & 27,8 \\
Byoordele $(\mathrm{N}=110)$ & 52 & 47,3 & 58 & 52,7 \\
Diensure $(\mathrm{N}=127)$ & 109 & 85,8 & 18 & 14,2 \\
Verlof $(\mathrm{N}=128)$ & 118 & 92,2 & 10 & 7,8 \\
Bevorderingsgeleenthede $(\mathrm{N}=107)$ & 54 & 50,5 & 53 & 49,5 \\
\hline
\end{tabular}

respondente $k a n$ 'n verklaring wees van die weinige respondente wat oor gemeenskapsverpleegkunde beskik het. (Die geïntegreerde kursus is ongeveer in 1970 in die Vrystaat ingestel.) 'n Persoon wat in gemeenskapsverpleegkunde gekwalifiseer is. beskik oor kennis van voetversorging, fisieke ondersoek en beraming. Dit is noodsaaklike kennis vir geregistreerde verpleegkundiges in tehuise. Tydens die meet van die kwaliteit van versorging van die 45 bejaardes was die beramings wat gedoen is soos in die rekord weerspieël onvolledig en die navorser het die afleiding gemaak dal daar 'n gebrek aan kennis is. Dit kan moontlik hier aan toegeskryf word.

Wat na-basiese registrasies betref was geen respondent in geriatriese verpleegkunde geregistreer nie. Volgens die navorser se mening is dit veral belangrik dat die verpleegkundiges wat die bestuurspos beklee of in bevel van ' $n$ tehuis is oor ' $n$ kwalifikasie in verpleegadministrasie moet beskik. Slegs een $(2,2 \%)$ het hierdie $k$ walifikasie gehad. Die navorser handhaaf hierdie siening omdat die persoon wat die bestuurspos of bevelpos beklee se pligte so uitgebreid is dat die

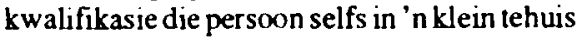
beter behourt toe te rus.

Tevredenheid of ontevredenheid van personeel met diensvoorwaardes en met betrekking tot voorraad en toerusting

Volgens tabel 2 het dit gebiyk dat die respondente meer tevrede as ontevrede was aangesien $(72,2 \%)$ met hul salaris, $(85,8 \%)$ met hul diensure en $(92,2 \%)$ met hul verlof tevrede was. Twee-en-vyftig persent was met hul byvoordele ontevrede en $(49,5 \%)$ met hul bevorderingsgeleenthede. Dit het geblyk dat tehuise nie met ander instansies soos byvoorbeeld die provinsiale administrasies kan meeding ten opsigte van behuisingsubsidies, uniformtoelae en die postestruktuur nie. Ten spyte hiervan was daar nie 'n hoë personeelomset in die tehuise nie. (Slegs $7,5 \%$ van die personeel was minder as een jaar in die tehuis werksaam.)

Vonrraad en toerustung word nie op die tabel aangedui nie. Alhoewel dit nie deel van diensvoorwaardes is nie, was dit vir die navorsers belangrik om die respondente se mening daaroor te verkry aangesien dit moellik is om verpleegsorg sonder voldoende voorraad en toenusting te lewer.

Agt-en-vyftig (43,3\%) was ontevrede met die voorraad en $40(29,8)$ ) het as rede aangevoer dat die voorraad onvoldoende is om goeie versorging te lewer. Veertig $(29,9 \%)$ was ontevrede met die toerusting en $35(26,1 \%)$ het gesê dat dit te $\min$ is.

Die redes hoekum respondente in 'n tehuis vir bejaardes werk

Volgens figuur 2 het $114(85,1 \%)$ aangedui dat hul ' $n$ spesiale belangstelling in bejaardes het Die ander redes was nie hoog aangeslaan nie 
Respondente se mening ten opsigte van hul kennis en vaardighede vergeleke met dié van kollegas in algemene hospitale

Hierdie vraag is ingesluit om te bepaal of die respondente hulself in 'n laer rolstatus plaas ten opsigte van kennis en vaardighede as hul eweknieë in hospitale. Twee-en-negentig respondente $(68,7 \%)$ het geglo dat hulle meer kennis en vaardighede in 'n algemene hospitaalpos as in ' $n$ tehuis pos benodig. Hierdie bevinding stem ooreen met die literatuur (Brower 1981:297). Volgens Brower (1981:297) word tehuispersoneel soms gestigmatiseer deur hul eweknieë en in 'n laer rolstatus geplaas. Die navorser is van mening dat hierdie siening van die personeel moontlik daarvoor verantwoordelik kan wees.

Die personeel het verskeie sieninge oor kliniese kennis uitgespreek. Elf $(11,9 \%)$ het geglo dat hulle onvoldoende kennis het om in ' $\mathrm{n}$ hospitaal te werk. Een-en-dertig $(33,7 \%)$ is van mening dat daar meer siektetoestande in hospitale voorkom as in 'n tehuis en dus sou hulle meer kennis nodig hê om daar te werk. Daar is ook deur $14(15,3 \%)$ angevoer dat verpleegsorg in tehuise slegs roetine werk is en daarvoor word kennis nie benodig nie. Ses-en-dertig $(39,1 \%)$ van die 92 het geen rede verskaf nie.

Twee-en-veertig respondente $(31,3 \%)$ het geglo hulle het nie meer kennis en vaardighede in 'n hospitaal as in 'n tehuis nodig nie. Slegs sewentien $(12,6 \%$ ) van die 42 het 'n rede verskaf. Hulle het aangevoer dat hulle professioneel opgelei is en dus oor voldoende kennis en vaardighede beskik. Dertien $(30,9 \%)$ was van mening dat bejaardes in tehuise aan verskillende siektetoestande ly en daarvoor het hulle net soveel kennis as in 'n hospitaal nodig. Slegs twee $(4,8 \%)$ het geantwoord dat hulle hulself op die hoogte hou van ontwikkelinge in verpleegkunde en twee (4.8\%) was van mening dat hulle opleiding gehad het en hul kennis dus voldoende is.

\section{Werkstevredenheld van respondente}

Honderd-twee-en-dertig van die respondente $(98.5 \%)$ het hulself as gelukkig en tevrede in hul werk beskou. Twee $(1,5 \%)$ van die respondente het hulself as net af en toe gelukkig beskou.

Hierdie hoë graad van tevredenheid kan toegeskryf word aan die belangstelling wat hulle in die bejaardes het. Die navorser maak hierdie afleiding op grond van die respons waarin $85,1 \%$ aangedui het dat hulle 'n spesiale belangstelling in bejaardes het. Daar kan ook aangeneem word dat hulle gelukkig en tevrede is omrede hulle self gekies het om in ' $n$ tehuis van bejaardes te werk.

\section{Redes vir respondente se werkstevredenheid}

Vier-en-sestig $(47,8 \%)$ respondente het as rede aangevoer dat "om met bejaardes te werk" en "om die bejaarde van hulp te wees" hulle gelukkig in hul werk maak (kyk tabel 1). Hierdie rede is intrinsiek in die werk geleë omdat dit verband hou met die aard en verantwoordelikheid van die werk. Dit stem dus met Herzberg se motiveringsteorie ooreen (Hand 1981:35). Die blydskap, dankbaarheid, afhanklikheid en waardering van die bejaardes is ook as rede deur $19(14,1 \%)$ van die respondente aangevoer. Die navorser is van mening dat die respondente voel hulle kry op die wyse erkenning. Volgens Herzberg se teorie is dit ook 'n ware motiveerder aangesien dit intrinsiek in die werk geleë is (Hand 1981:35).

Twee redes is aangevoer wat volgens die navorser se mening ekstrinsiek van aard is. Twee $(1,5 \%)$ respondente het aangevoer dat die rustigheid van 'n tehuis hulle gelukkig maak en $26(19,4 \%)$ sê hulle is gelukkig omdat hulle goeie samewerking met medepersoneel geniet.

Die intrinsieke redes vir tevredenheid in die werksituasie wat deur $83(61,9 \%)$ aangevoer is, verklaar hoekom $98,5 \%$ van die respondente gelukkig en tevrede in hul werk is.

\section{Tekens van uitbranding}

Die skaal het getoon dat die minderheid oor die algemeen tekens van uitbranding ervaar het. Slegs twee faktore het in die "soms" kolom 'n persentasie van bo $50 \%$ behaal, naamlik "ek voel omgekrap wanneer die roetine by die werk omvergegooi word" en "ek voel bedreig wanneer iemand my kennis toets". Volgens Eliopoulos (1983:60) kan onbuigsaamheid 'n teken van uitbranding wees maar Castledine (1982:19) dui weer aan dat verpleegkundiges roetines verkies omdat dit hulle veilig laat voel.

\section{Meningsopname van wie gewoonlik eerste ' $n$ verandering in ' $n$ bejaarde se toestand waarneem}

Twee-en-tagtig punt agt persent $(82,8 \%)$ het angedui dat dit gewoonlik die verpleegassistent is wat eerste ' $n$ verandering in 'n bejaarde se toestand waarneem. Volgens Mezey en Lynaugh (1989:776) is dit gewoonlik die verpleegassistente wat die meeste tyd aan bejaardes bestee en is hulle dan ook die persone wat gewoonlik die bejaardes moet observeer en besluite moet neem oor hulle toestand. Die verpleegassistente moet gewoonlik in die nag besluite neem, want in slegs twee tehuise was daar 'n geregistreerde verpleegkundige op nagdiens.

Op dagdiens moet die verpleegassistent besluit of ' $n$ bejaarde se toestand $v$ an so ' $n$ aard is dat sy dit aan die verpleegkundige moet rapporteer. Aangesien die meerderheid aangetoon het dat verpleegassistente gewoonlik eerste die verandering waarneem, beklemtoon dit die belangrike rol wat indiensopleiding aan verpleegassistente behoort te speel om hulle vir die belangrike besluite wat hulle moet neem voor te berei.
Indiensopleiding

Vier-en-sestig persent van respondente het geen indiensopleiding ontvang nie en verreweg die meerderheid $(85,11 \%)$ het 'n behoefte aan indiensopleiding uitgespreek. Dit is ' $n$ behoefte wat ook redelik maklik bevredig kan word. Indiensopleiding verhoed dat personeel se kliniese vaardighede "verroes", dit verseker dat hulle op die hoogte van nuwe ontwikkelinge in die verpleging bly en stimuleer hulle om met meer insig te verpleeg. Sodoende verbeter die kwaliteit van sorg wat hulle lewer.

Houding en kennis van verpleegpersoneel teenoor bejaardheid, verswakte bejaardes en sekere aspekte van verpleegsorg

Vir besprekingsdoeleindes is slegs sommige van die 17 stellings geselekteer en word hulle in tabel 3 weergegee. Dit blyk duidelik uit stellings $16.1,16.8,16.11,16.13$ en 16.17 dat personeel vooroordele teenoor bejaardes het en ook ' $n$ gebrek aan kennis openbaar. Personeel het ook ' $n$ bepaalde persepsie van bewaarsorg gehandhaaf (kyk stellings 16.3). Slegs by een stelling was daar 'n duidelike onderskeid ten opsigte van die response van die verskillende kategorieë wat aandui dat die verpleegkundiges oor meer kennis as die verpleegassistente beskik (kyk stelling 16.10). Alhoewel in die minderheid is daar egter ook positiewe response verkry aangesien die personeel ten gunste van rehabilitasie was (kyk stellings 16.15 en 16.16) wat teenstrydig is met ander vrae wat bewaarsorg beklemtoon. Dit is ook vir die personeel interessant om met die bejaardes te werk en die glimlag van 'n verswakte bejaarde is vir hulle ' $n$ goeie beloning en dien dus ook as motivering (kyk stellings 16.4 en 16.7).

Volgens die berekenings was daar 'n klein verskil in persentasie tussen die verpleegassistente, ingeskrewe verpleegkundiges en verpleegkundiges. Volgens figuur 3 was die verpleegkundiges se telling slegs $9,9 \%$ hoër as dié van die verpleegassistente. In die lig van die feit dat dit die verpleegkundige is wat as rolmodel moet optree en gewoonlik die indiensopleiding moet gee word daar meer van haar verwag.

\section{Kennis van geneesmiddels}

Slegs die verpleegkundiges het hicrdie vraag voltooi aangesien geneesmiddel toediening nie deel van die bestek van praktyk van die ander kategorieë is nie. Twee-en-dertig $(71,1 \%)$ van die respondente het geglo dat daar 'n leemte in hul kennis is ten opsigte van newe-effekte van geneesmiddels. Ten spyte daarvan het $34(75,6 \%)$ voorstelle oor voorskrifte aan die geneesheer gemaak. Volgens die navorser se mening is die verpleegkundige, in die lig van haar kennis van die bejaardes under haar sorg, in staat om voorstelle aan die geneesheer te maak maar slegs indien haar kennis voldoende is. Die navorser het wargeneem dat 


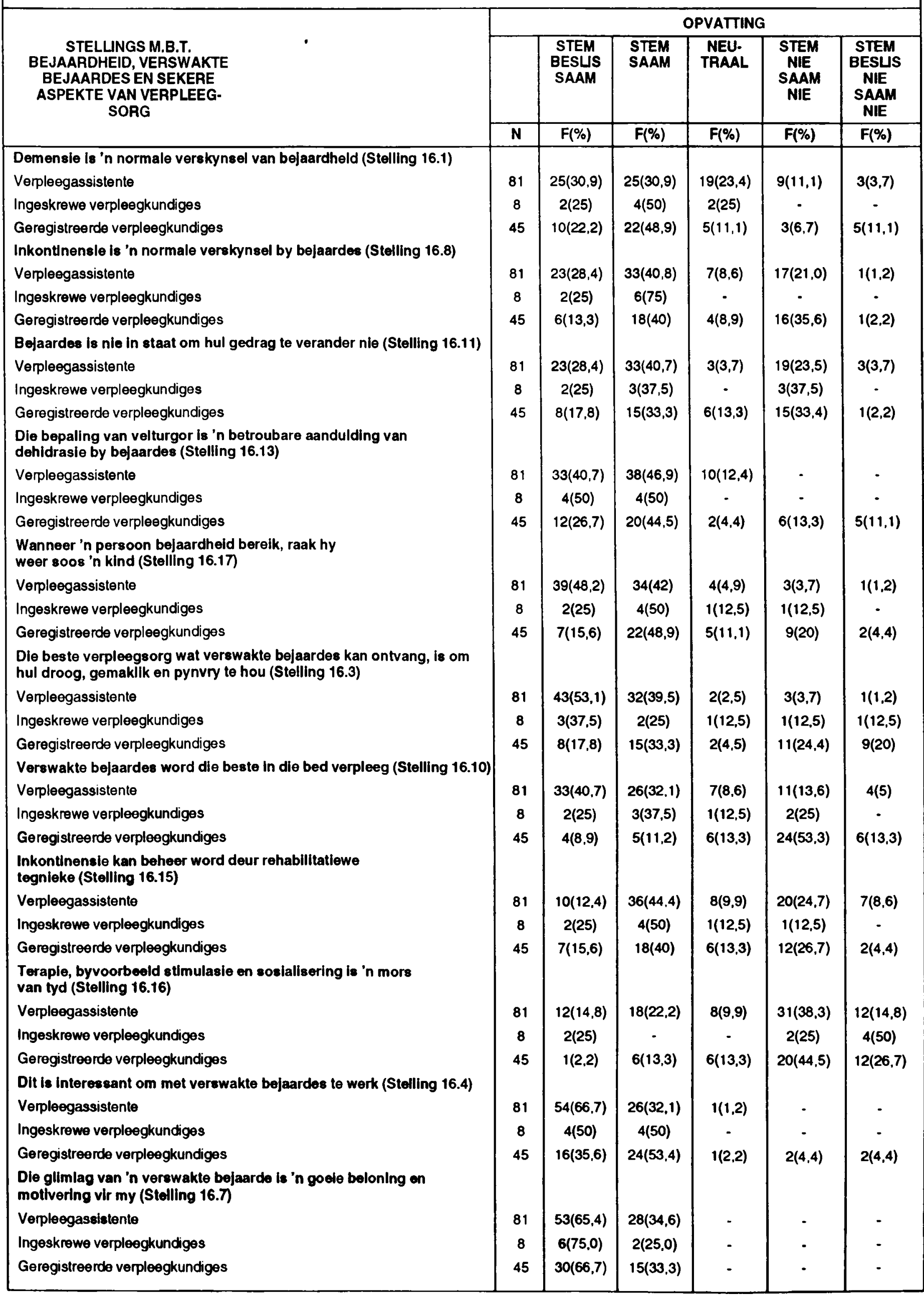




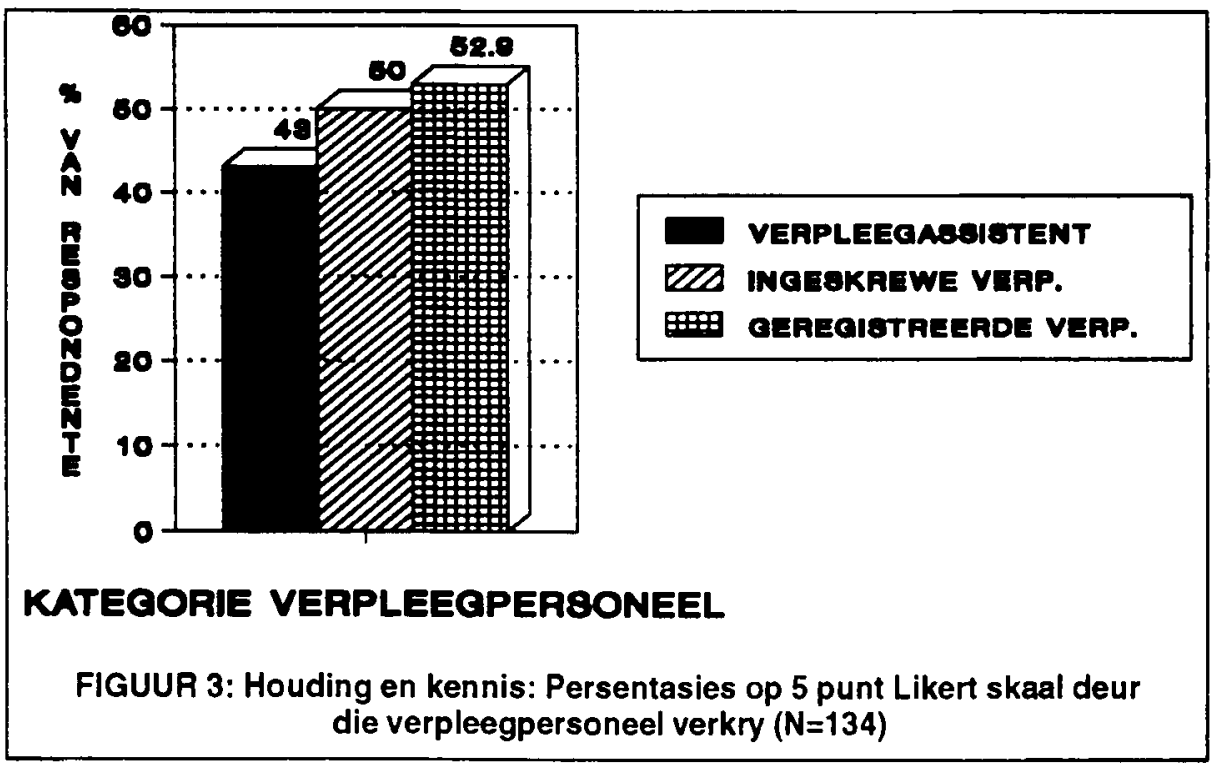

verpleegkundiges dikwels die geneesheer skakel en versoeke oor geneesmiddels rig. Daar is ook bejaardes wat nie jaarliks deur ' $n$ geneesheer besoek word nie, daarom speel die verpleegkundige ' $n$ belangrike rol in geneesmiddelhantering in tehuise vir bejaardes.

Dit was verblydend om te sien dat die meerderheid op al die stellings positief gereageer het wat aandui dat hulle kennis van basiese feite oor geneesmiddels voldoende is. Die verpleegkundiges in die studie was egter nie bewus van die interaksies tussen die verskillende geneesmiddels wat vir 43 bejaardes voorgeskryf is nie (daar was 29 moontlike interaksies) wat aandui dat hulle slegs oor basiese kennis beskik terwyl Eliopoulos (1983:65) van mening is dat kennis van geneesmiddels ' $n$ prioriteit moet wees en dat baie meer as slegs basiese kennis nodig is.

\section{Implikasies}

Ten einde hoë kwaliteit verpleegsorg aan geriatriese pasiënte in tehuise van bejaardes te lewer is dit noodsaaklik dat die verpleegpersoneel oor 'n positiewe houding teenoor bejaardes beskik. Hulle kennis behoort nie net voldoende te wees nie, maar verpleegpersoneel behoort ook op datum te bly. Veral ten opsigte van die geregistreerde verpleegkundige wat as rolmodel moet optree ten opsigte van houding en om kennis oor te dra, blyk dit noodsaaklik te wees. Om hierdie doelwitte te bereik, word die volgende aanbevelings gedoen.

\section{AANBEVELINGS}

- Verpleegkundiges behoort hul kennis op datum te bring van verpleegproses, behoeftes van bejaardes, farmakologie en bewus te wees van hul houding teenoor bejaardes.

- Verpleegkundiges moet aangemoedig word om by 'n geriatriese verpleegkundige besprekingsgroep aan te sluit om mekaar op te skerp en idees- en kennis uit te ruil.
BURNS, N. \& GROVE, S.K. (1987). The practice of nursing research: Conduct, critique and utilization. International Edition, Philadelphia: W.B: Saunders.

CAMPBELL, M.E. (1971). Study of the attitudes of nursing personnel toward the geriatric patient, Nursing Research, 20(2):147-151

CASTLEDINE, G. (1982). Sorry I haven't got time, Nursing Mirror, 155(11):17-20.

CHANDLER, J.T., RACHAL, J.R. \& KAZELSKIS, R. (1986). Attitudes of long-term care nursing personnel toward the elderly, The Gerontologist, 26(5):551-555.

CHARTOCK, P., NEVINS, A., RZETELNY, H. \& GILBERGO, P. (1988). A mental health training program in nursing homes. The Gerontologist, 28(4):503-507. verpleegassistente gerig is, ten opsigte van basiese verpleegsorg is 'n sterk aanbeveling. Dit kan deur geregistreerde verpleegkundiges plaaslik aangebied word.

\section{SLOT}

In hierdie studie is uitgewys dat die houdings, vooroordele en persepsies van verpleegpersoneel teenoor en van bejaardes sowel as hul kennis op bepaalde terreine, nie bevorderlik vir die welsyn van verswakte bejaardes was nie. Dit het geblyk dat veral die geregistreerde verpleegkundiges geisoleerd is en nie genoeg in hul werk gestimuleer word nie. Ten spyte hiervan het die meerderheid gekies om in ' $n$ tehuis te werk aangesien hulle 'n spesiale belangstelling in bejaardes het. Die intrinsieke redes vir tevredenheid in die werksituasie verklaar hoekom die respondente gelukkig en tevrede in hul werk is.

Daar rus egter 'n groot verantwoordelikheid op die verpleegkundige as rolmodel vir die ander kategorieë om ten spyte van moeilike omstandighede die uitdagings van verpleegsorg in tehuise van bejaardes te aanvaar.

\section{VERWYSINGS}

ARMSTRONG-ESHER, C.A., SANDILANDS, M.C. \& MILLER, D. (1989). Attitudes and behaviours of nurses towards the elderly in an acute care setting, Journal of Advanced Nursing, 14(1):34-41.

BROOKE, V. (1989). Your helping hand, Geriatric Nursing, 10(5):126-128.

BROWER, H.T., SOLOMON, J. \& TAPPEN, R.M. (1982). A symposium on long-term care, Journal of Gerontological Nursing, 8(1):9-15
DELORA, J.R. \& MOSES, D.V. (1969) Speciality preferences and characteristics of student nurses in a baccalaureate program, Nursing Research. 18(3): $137-144$

ELIOPOULOS, C. (1983). Nursing administration of long-term care. Rockville: Aspen Systems Corporations.

GILLIS, M. (1973). Attitudes of nursing personnel toward the aged, Nursing Research. 22(6):517-520.

GLASSPOOLE, L.A. \& AMAN, M.G (1990). Knowledge, attitude, and happiness of nurses working with gerontological patients, Journal of Gerontological Nursing, 16(2):11-13.

GUNTER, L.M. (1971). Students' attitudes toward geriatric nursing, Nursing Outlook, 19(7):466-469

HAND, L. (1981). Nursing supervision. Reston, VA: Reston Publishing Co.

HELLER, B.R., BAUSELL, F.R.B. \& NIHOS, M. (1984). Nurses' perceptions of rehabilitation potential of institutionalized aged, Journal of Gerontological Nursing, 10(7):22-27.

HIRST, S.P. (1986). Learning needs of caregivers, Journal of Gerontolugical Nursing, 12(3):24-28.

HOLT'L, G.A. (1982). Nurses' aides in nursing homes: Why are they satisfied? Journal of Gerontological Nursing, 8(5):265-271.

INGHAM, R \& FIELDING, P. (1985), A review of the nursing literature on attitudes towards old people, International Journal of Nursing Studies, 22(3):171-181. 
KAYSER, J.S. \& MINNIGERODE, F.A. (1975). Increasing nursing students' interest in working with aged patients, Nursing Research, 24(1):23-26.

KOGAN, N. (1961). Attitudes toward old people. The development of a scale and an examination of correlates, Journal of Abnormal and Social Psychology, 62(1):44-54.

MEZEY, M.D. \& LYNAUGH, J.E. (1989). The teaching nursing home program: Outcomes of care, Nursing Clinics of North America, 24(3):769-779.

MURRAY, R.B. \& ZENTNER, J.P. (1985). Nursing asssessment and health promotion through the life span. Englewood Cliffs: Prentice-Hall, Inc.

NODHTURFT, V.L., BANKS, D.O. \& MacMULLEN, J.A.S. (1986). VA study: Training the geriatric nurse, Journal of Gerontological Nursing, 12(5):24-29.

PALMORE, E. (1977). Facts on aging, a short quiz, The Gerontologist, 17(4):315-320.

PHILLIPS, C. (1987). Staff turnover in nursing homes for the aged: $A$ review and research proposal, International Journal of Nursing Studies, 21(1):45-57.

SCOTT, R.R., BRAMBLE, K.J. \& GOODYEAR, N. (1991). How knowledge and labeling of dementia affect nurses' expectations, Journal of Gerontological Nursing, 17(1):21-24.

SEERS, C. (1986). Talking to the elderly and its relevance to care, Nursing Times, 82(1):50-54.
SLABBER, C.F. (1985). Openingstoespraak: Voordragte gelewer ten tye van die opknappingskursus vir huisartse. Mededelings van die Fakulteit van Geneeskunde, Bloemfontein: UOVS

SLEVIN, O.D.A. (1991). Ageist attitudes among young adults: Implications for a caring profession, Journal of Advanced Nursing, 16(10):1197-1205.

SMITH, M. (1990). Geropsychiatric education programs, Journal of Psychosocial Nursing, 28(12):8-12.

SNAPE. J. (1986). Nurse's attitudes to care of the elderly, Journal of Advanced Nursing, 11(5):569-572.

TRICHARD, L., ZABOW, A. \& GILLS, L.S. (1982). Elderly persons in old-age homes: A medical, psychiatric and social investigation, South African Medical Journal, 61(17):624-627.

TUCKMAN, J. \& LORGE, I. (1953). Attitudes toward old people. The Journal of Social Psychology, 37:249-260.

WAXMAN, H.M., ERWIN, A., CARNER, E.A. \& BERKENSTOCK, G. (1984). Job turnover and job satisfaction among nursing home aides, Journal of Gerontological nursing, 24(5):503-509.

WELLS, T.J. (1980). Problems in geriatric nursing care. New York: Churchill Livingstone.

WILSON, H.S. (1989). Introducing research in nursing. 2nd ed. Menlo Park: Addison Wesley Publishing Inc.
WRIGHT, (1988). A reconceptualization of the "negative staff attitudes and poor care in nursing homes" assumption, The Gerontologist, 28(6):813-820

YURICK, A.G., ROBB, S.S., SPIER, B.E. \& EBERT, N.J. (1980). The aged person and the nursing process. New York: Appleton-Century-Crofts.

\section{ERKENNING}

RGN (Sentrum vir Gerontologie), SAVV en Instituut van die OVS vir finansiële ondersteuning.

Mev. Elsabé Gleeson vir die tikwerk

PAULA P DU RAND

M.Soc.Sc.(Verpl.), UOVS Lektrise

Departement Verpleegkunde UNIVERSITEIT VAN DIE ORANJE-VAYSTAAT

MOLLY V VERMAAK, M.Soc.Sc.(Verpl.), UOVS Senior Lektrise

Departement Verpleegkunde UNIVERSITEIT VAN DIE ORANJE-VRYSTAAT 